\title{
EFFECTS OF ANTI-ETHYLENE TREATMENTS ON ETHYLENE PRODUCTION AND ANTIOXIDANT ACTIVITIES IN CUT SPRAY CARNATION
}

\author{
Mahnaz Karimi ${ }^{1}$, Moazzam Hassanpour Asil ${ }^{2} *$, Ghorbanali \\ Nematzadeh ${ }^{3}$ and Hedayat Zakizadeh ${ }^{4}$ \\ ${ }^{1}$ Department of Horticultural Sciences, Faculty of Agricultural Sciences \\ University of Guilan, Rasht, IRAN \\ e-mail: Karimi1320@gmail.com \\ ${ }^{2}$ Department of Horticultural Sciences, Faculty of Agricultural Sciences \\ University of Guilan, Rasht, IRAN \\ ${ }^{3}$ Genetic and Agricultural Biotechnology Institute of Tabarestan \\ Sari Agricultural Sciences and Natural Resources University, Sari, IRAN \\ e-mail: gh.nematzadeh@sanru.ac.ir \\ ${ }^{4}$ Department of Horticultural Sciences, Faculty of Agricultural Sciences \\ University of Guilan, Rasht, IRAN \\ e-mail: zakizadeh55@yahoo.com \\ *Corresponding author: m.hassanpourasil.h@gmail.com; hassanpurm@guilan.ac.ir
}

(Received September 9, 2012/Accepted October 29, 2012)

\section{A B S T R A C T}

The present investigation was aimed to study changes in ethylene production, ACC content and antioxidant enzymes of cut spray carnation (Dianthus caryophyllus L.) flowers that had been treated with amino-oxyacetic acid (AOA), benzyladenine (BA) and 1-methylcyclopropene (1-MCP). Maximum vase life in 'Optima' spray carnations was obtained with $0.6 \mathrm{mg} \mathrm{l}^{-1} 1$-MCP. Ethylene production was significantly decreased by AOA at concentrations over $100 \mathrm{mg} \mathrm{l}^{-1}$, BA at $30 \mathrm{mg} \mathrm{l}^{-1}$, and 1-MCP at all concentrations, compared with the control. A significant increase in ACC content was observed in 1-MCP treated cut flowers compared with the control. However, the decline in ACC content was observed after using 100 or $150 \mathrm{mg} \mathrm{l}^{-1}$ AOA. A significant increase in SOD, CAT and POX enzyme activities was observed in the treatment with $0.6 \mathrm{mg} \mathrm{l}^{-1} 1-\mathrm{MCP}$.

Key words: amino-oxyacetic acid, benzyladenine, 1-methylcyclopropene, vase life 


\section{INTRODUCTION}

Postharvest senescence is a major limitation to the marketing of many species of cut flowers and considerable efforts have been devoted to developing postharvest treatments to extend the marketing period (Nichols, 1977; Rattanawisalanona et al., 2003). Ethylene is the major coordinator of senescence in many flowers (Nichols, 1977). It is a gaseous plant hormone synthesized by the oxidation of 1aminocyclopropane-1-carboxylic acid (ACC). In flowers where ethylene has been implicated in the control of floral senescence, the use of ethylene inhibitors such as amino-oxyacetic acid (AOA), norbornadiene or 1-methylcyclopropene (1-MCP) usually prolongs the vase life of cut flowers (Serek et al., 1995; Ferrante et al., 2006). The ACC content of senescing miniature Rose flowers pre-treated with 1-MCP was clearly higher than in the untreated control (Muller et al., 2001). AOA is used for extending the vase life of cut flowers which are sensitive to ethylene (Rattanawisalanona et al., 2003). AOA inhibited senescence and delayed flower abscission in Salvia splendens (Ferrante et al., 2006). Treatment with benzyladenine (BA) inhibited ethylene production in rose flowers as well as improved sensitivity against ethylene (Pemberton et al., 1997). Cytokinins have been particularly effective in delaying senescence of cut carnation flowers by inhibiting ethylene biosynthesis (Cook et al., 1985). The cytokinin benzyladenine increases the vase life of Eustoma (Huang and Chen, 2002).
Similarly, Karimi and Hassanpour Asil (2010) reported that treating Eustoma cut flowers with $50 \mathrm{mg} \mathrm{l}^{-1} \mathrm{BA}$ (a cytokinin) in combination with $3 \%$ sucrose delayed flower senescence and ethylene production. Treatment of Iris cut flowers with $0.22 \mathrm{mM} \mathrm{BA}$ for $24 \mathrm{~h}$ at $20{ }^{\circ} \mathrm{C}$ significantly extended their vase life (Macnisha et al., 2010). Free radicals are known to participate in plant senescence (Dhindsa et al., 1981). The cells mount a defence response against the accumulation of free radicals by increasing catalase (CAT) and superoxide dismutase (SOD) activity (Khan, 2006). Ethylene leads to a decline in peroxidation and prolongs the life of cut carnations. This phenomenon suggests a relationship between free radical generation and ethylene production (Mayak et al., 1983). In carnation petals, SOD activity decreases and CAT activity increases during senescence (Droillard et al., 1989). AOA treatment does not alter the activities of antioxidant enzymes as compared to control carnation petals (Carlos et al., 1996). The research reported in this paper was undertaken to study changes in ethylene production, ACC content and activity of antioxidant enzymes in spray carnation flowers that had been immersed in AOA, BA and 1MCP in order to provide basic information for future strategies to increase flower longevity and quality.

\section{MATERIAL AND METHODS}

\section{Plant material and treatments}

Cut flowers of spray carnation (Dianthus caryophyllus L. cv. Optima) were purchased from a commercial grower in Pakdasht, Va- 
ramin, Iran. At purchasing time, the flowers were at the usual commercial stage of flowering when the first flower out of the six to eight flower buds on the stem was almost fully opened. The stems were trimmed to $40 \mathrm{~cm}$, immersed with their cut ends in 50,100 or $150 \mathrm{mg} \mathrm{l}^{-1} \mathrm{AOA}$ and 10 , 20 or $30 \mathrm{mg} \mathrm{l}^{-1}$ BA solutions for $12 \mathrm{~h}$. For 1-MCP treatment, the cut flowers were treated with $0.4,0.6$, or $0.8 \mathrm{~g} \mathrm{~m}^{-3}$ of 1-methylcyclopropene for $12 \mathrm{~h}$ at $22^{\circ} \mathrm{C}$. The 'Optima' flowers were placed in $118 \times 28 \times 44 \mathrm{~cm}$ boxes for each treatment and sealed in polyethylene bags. Each box was sealed well with a plastic cover. Volatile 1-MCP was released from the powder of $0.14 \%$ Ethylbloc $^{\circledR}$ (Rohm and Hass Philadelphia, PA) in the sealed boxes by adding $2 \mathrm{ml}$ of water with a syringe. After treatment, the cut flowers were placed in a $500 \mathrm{ml}$ flask with $400 \mathrm{ml}$ of distilled water and kept at $20^{\circ} \mathrm{C} \pm 2{ }^{\circ} \mathrm{C}, 70-80 \%$ relative humidity, and $12 \mathrm{~h}$ photoperiod with $15 \mu \mathrm{mol} \mathrm{m} \mathrm{m}^{-2}$ irradiance from cool white fluorescent lamps throughout the experiment. Vase life was determined as the time to wilting of more than one-third of the flowers in the inflorescences.

\section{Measurement of ethylene produc- tion}

For ethylene measurement, one flower of each treatment was cut directly below the calyx and placed in a closed jar $(250 \mathrm{ml})$ at $23^{\circ} \mathrm{C}$. After $2 \mathrm{~h}, 1 \mathrm{ml}$ gas samples were extracted and injected into a gas chromatograph (Shimadzu Gas Chromatograph equipped with an activated alumina column fitted with a flame ionization detector).

\section{Enzyme assays}

\section{Catalase (CAT; EC 1. 11.1.6)}

For catalase assay, the reaction mixture contained $15 \mathrm{mM} \mathrm{H}_{2} \mathrm{O}_{2}$, up to $100 \mu \mathrm{l}$ of homogenate ( $7 \mathrm{mg}$ protein $\mathrm{ml}^{-1}$ ) with $0.2 \%(\mathrm{v} / \mathrm{v})$ Triton $\mathrm{X}$ 100 in $50 \mathrm{mM}$ potassium phosphate buffer (pH 7.0) (Aebi, 1983). All enzyme activities and protein concentration were quantified spectrophotometrically (6405 UV/ Vis, JENWAY, ENGLAND).

\section{Peroxidase (POX; EC 1.11.1.7)}

For peroxidase assay, petals (100 mg FW) were crushed in a phosphate buffer (0.1 M, pH 7.0) containing 15\% (w/w) PVPP, $2 \mathrm{mM}$ EDTA and $0.5 \%$ (v/v) Triton X-100. The homogenate was centrifuged at $10,000 \mathrm{rpm}$ for 20 $\mathrm{min}$. and the supernatant was assayed for POD. Peroxidase activity was determined following oxidation of $\mathrm{o}$ dianisidine in the presence of $\mathrm{H}_{2} \mathrm{O}_{2}$ at $470 \mathrm{~nm}$ (Aebi, 1983).

\section{Superoxide dismutase (SOD, EC 1.15.1.1)}

Superoxide dismutase activity was assayed as described by Beauchamp and Fridovich (1971). The reaction mixture was prepared by mixing $0.1 \mathrm{mM}$ nitroblue tetrazolium, $0.1 \mathrm{mM}$ EDTA, and $50 \mu \mathrm{M}$ xanthine and xanthine oxidase in $50 \mathrm{mM}$ potassium phosphate buffer, $\mathrm{pH}$ 7.8. One unit of SOD is defined as the amount of enzyme that inhibits the control rate by $50 \%$ (0.025 units of absorbance at 550 $\mathrm{nm} \mathrm{min}^{-1}$ ) (McCord and Fridovich, 1969). 
Extraction and analysis of ACC

$2 \mathrm{~g}$ of crushed, frozen tissue (petal) was homogenized in $4 \mathrm{ml}$ of 5\% sulfosalicylic acid (SSA) solution, and centrifuged for $10 \mathrm{~min}$ at $3,090 \times \mathrm{g}$ in a pre-cooled centrifuge at $4{ }^{\circ} \mathrm{C}$. ACC was assayed essentially as described by Bulens et al. (2011). Briefly, $0.4 \mathrm{ml}$ of $10 \mathrm{mM} \mathrm{HgCl}_{2}$ was added to $1.4 \mathrm{ml}$ of extract in a $9 \mathrm{ml}$ vial, which was immediately sealed with a serum cap. Approximately $0.2 \mathrm{ml}$ of the $\mathrm{NaOH} / \mathrm{NaOCl}$ mixture was injected into the vial through the serum cap. The mixture was vortexed for 5 seconds and allowed to react for $4 \mathrm{~min}$. on melting ice. The sample was vortexed again for 5 seconds to release all ethylene into the vial headspace. Following the second vortexing, a $1 \mathrm{ml}$ gas sample was removed for ethylene determination by gas chromatography.

\section{Experimental design and statistical analysis}

This experiment was conducted in a completely randomized design with four replications. Results were analysed using SAS software. Mean comparisons to identify significant difference between treatments were performed using least significant difference (LSD).

\section{RESULTS}

\section{Vase life}

The vase life of cut spray carnation flowers is presented in Table 1. The control flowers exhibited a short vase life. Treatment with 1-MCP (at all concentrations), AOA (100 or $150 \mathrm{mg} \mathrm{l}^{-1}$ ) and BA (30 $\left.\mathrm{mg} \mathrm{l}^{-1}\right)$ significantly extended flower vase life
(Tab. 1). However, the longevity of the flowers kept in 10 or $20 \mathrm{mg} \mathrm{l}^{-1} \mathrm{BA}$, and $50 \mathrm{mg} \mathrm{l}^{-1}$ AOA was as short as that of the flowers kept in distilled water. The use of $0.6 \mathrm{mg} \mathrm{l}^{-1} 1$-MCP resulted in a greater extension in vase life (16.3 days) than the other treatments.

\section{Ethylene production}

Treatment with 1-MCP (at all concentrations), AOA (100 or $150 \mathrm{mg} \mathrm{l}^{-1}$ ) and BA (30 $\left.\mathrm{mg} \mathrm{l}^{-1}\right)$ significantly decreased the production of ethylene. The best means of inhibiting ethylene production was with $0.6 \mathrm{mg} \mathrm{l}^{-1}$ 1-MCP (Fig. 1). Ethylene production increased in the control, and after using 10 or $20 \mathrm{mg} \mathrm{l}^{-1} \mathrm{BA}$, and $50 \mathrm{mg} \mathrm{l}^{-1}$ AOA. Evaluation of the regression relationship between vase life and ethylene showed that with increasing ethylene production, vase life decreased (Fig. 2).

\section{Antioxidant enzymes}

Significantly higher activities of SOD, CAT and POD were observed in petals when cut spray carnations were treated with 1-MCP. Moreover, SOD, CAT and POX activities were significantly higher in the AOA (100 or $150 \mathrm{mg} \mathrm{l}^{-1}$ ) and BA (30 $\mathrm{mg} \mathrm{l}^{-1}$ ) treatments compared with the untreated plants (Tab. 1).

\section{Changes in ACC content of cut spray carnation}

The maximum ACC content was observed in the treatment with $0.6 \mathrm{mg} \mathrm{l}^{-}$ ${ }^{1} 1$-MCP $\left(10 \mathrm{nmol} \mathrm{g}^{-1} \mathrm{FW}\right)$. In contrast, application of AOA in high concentrations significantly decreased the ACC content in the flowers compared with 1MCP and BA, and the untreated control (Fig. 3). 
Effects of anti-ethylene treatments on ethylene production...

Table 1. Vase life and enzyme activity (superoxide dismutase, peroxidase and catalase) of cut spray carnation flowers subjected to different treatments.

\begin{tabular}{lcccc}
\hline $\begin{array}{c}\text { Treatment } \\
{\left[\mathrm{mg} \mathrm{l}^{-1}\right]}\end{array}$ & $\begin{array}{c}\text { Vase life } \\
{[\text { days }]}\end{array}$ & $\begin{array}{c}\text { SOD } \\
{\left[\mathrm{U} \mathrm{mg} \mathrm{Pro}^{-1}\right]}\end{array}$ & $\begin{array}{c}\text { POX } \\
{\left[\mathrm{nmol} \mathrm{min}^{-1} \mathrm{mg} \mathrm{Pro}^{-1}\right]}\end{array}$ & $\begin{array}{c}\text { CAT } \\
{\left[\mathrm{nmol} \mathrm{min}^{-1} \mathrm{mg} \mathrm{Pro}^{-1}\right]}\end{array}$ \\
\hline $\begin{array}{l}\text { Distilled water } \\
\text { (Control) }\end{array}$ & $5.2 \mathrm{~d}^{*}$ & $16.11 \mathrm{~d}$ & $6.01 \mathrm{f}$ & $0.59 \mathrm{f}$ \\
BA 10 & $5.2 \mathrm{~d}$ & $16.00 \mathrm{~d}$ & $6.65 \mathrm{f}$ & $0.57 \mathrm{f}$ \\
BA 20 & $5.5 \mathrm{~d}$ & $15.98 \mathrm{~d}$ & $6.00 \mathrm{f}$ & $0.60 \mathrm{f}$ \\
BA 30 & $8.6 \mathrm{c}$ & $18.88 \mathrm{c}$ & $10.11 \mathrm{e}$ & $0.95 \mathrm{e}$ \\
AOA 50 & $5.6 \mathrm{~d}$ & $16.08 \mathrm{~d}$ & $6.45 \mathrm{f}$ & $0.64 \mathrm{f}$ \\
AOA 100 & $12.3 \mathrm{~b}$ & $21.12 \mathrm{~b}$ & $12.40 \mathrm{~d}$ & $1.13 \mathrm{~d}$ \\
AOA 150 & $13.3 \mathrm{~b}$ & $21.34 \mathrm{~b}$ & $14.19 \mathrm{bc}$ & $1.19 \mathrm{c}$ \\
1-MCP 0.4 & $12.3 \mathrm{~b}$ & $22.15 \mathrm{~b}$ & $15.45 \mathrm{~b}$ & $1.20 \mathrm{c}$ \\
1 -MCP 0.6 & $16.3 \mathrm{a}$ & $26.43 \mathrm{a}$ & $18.88 \mathrm{a}$ & $1.35 \mathrm{a}$ \\
1 -MCP 0.8 & $13.0 \mathrm{~b}$ & $22.76 \mathrm{~b}$ & $16.21 \mathrm{~b}$ & $1.24 \mathrm{~b}$ \\
\hline
\end{tabular}

*Means within each column followed by different letters are significantly different $(\mathrm{p}=0.05)$

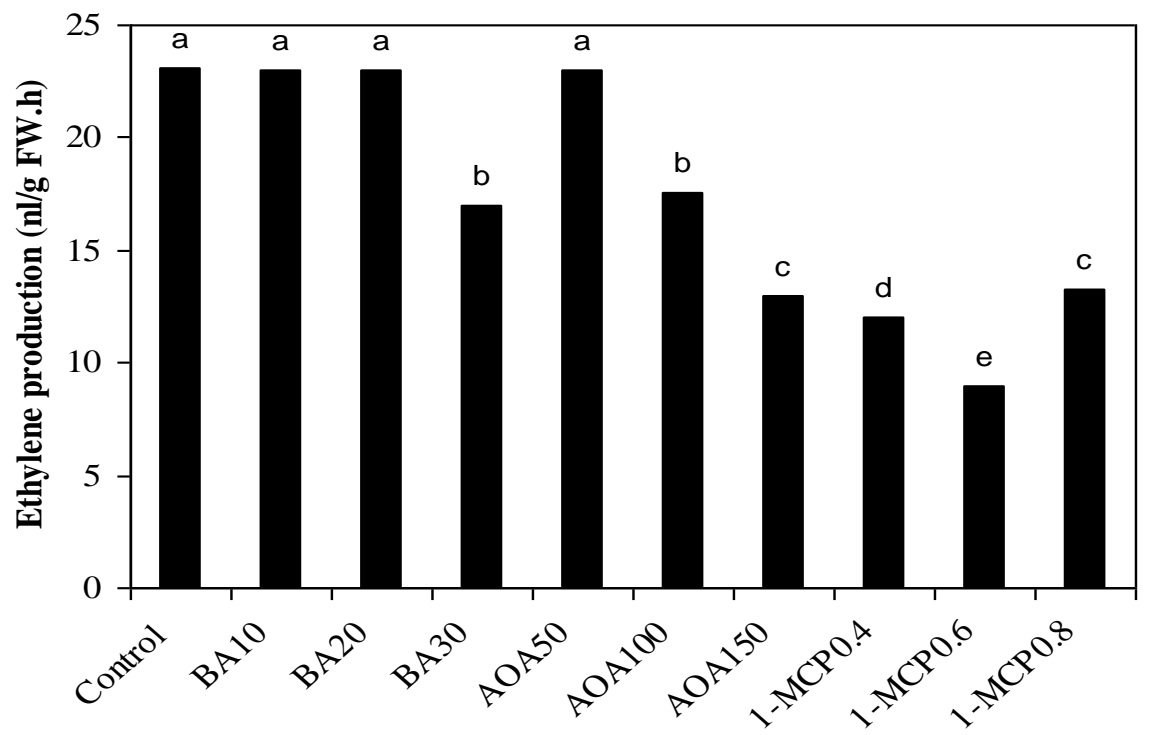

Figure 1. Ethylene production by flowers in response to treatment with different concentrations of BA, AOA and 1-MCP 
M. Karimi et al.

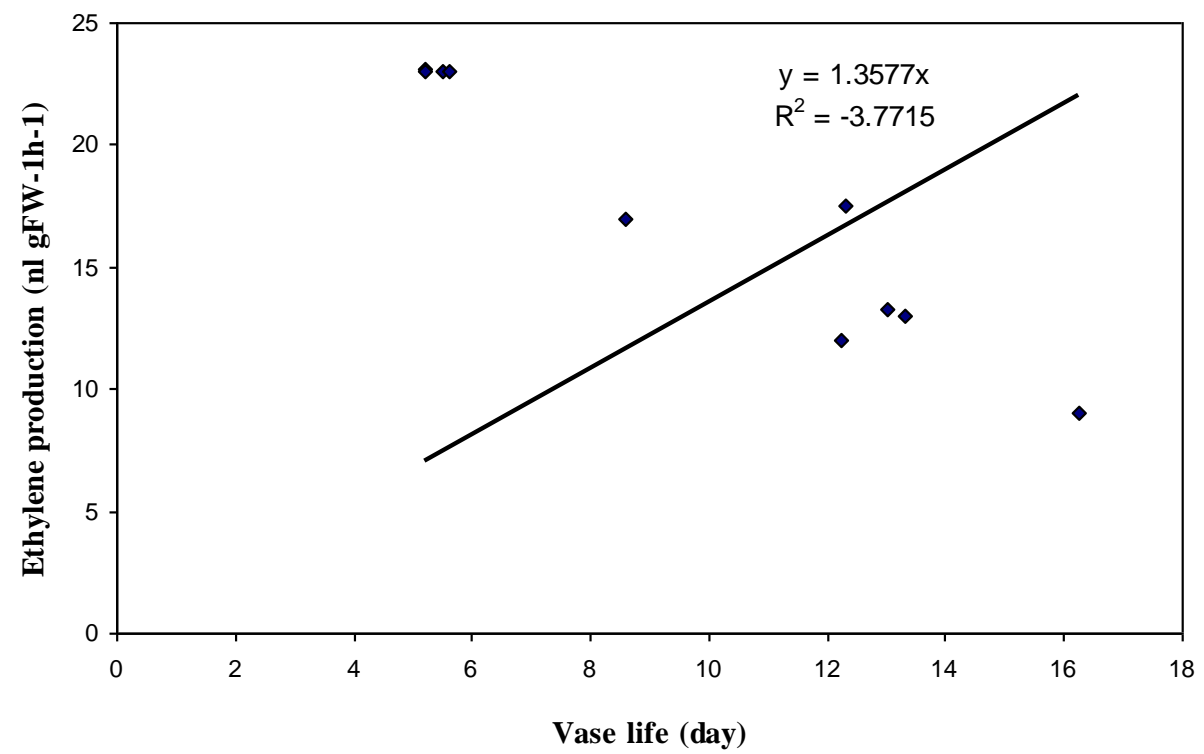

Figure 2. Regression relationship between ethylene production and vase life

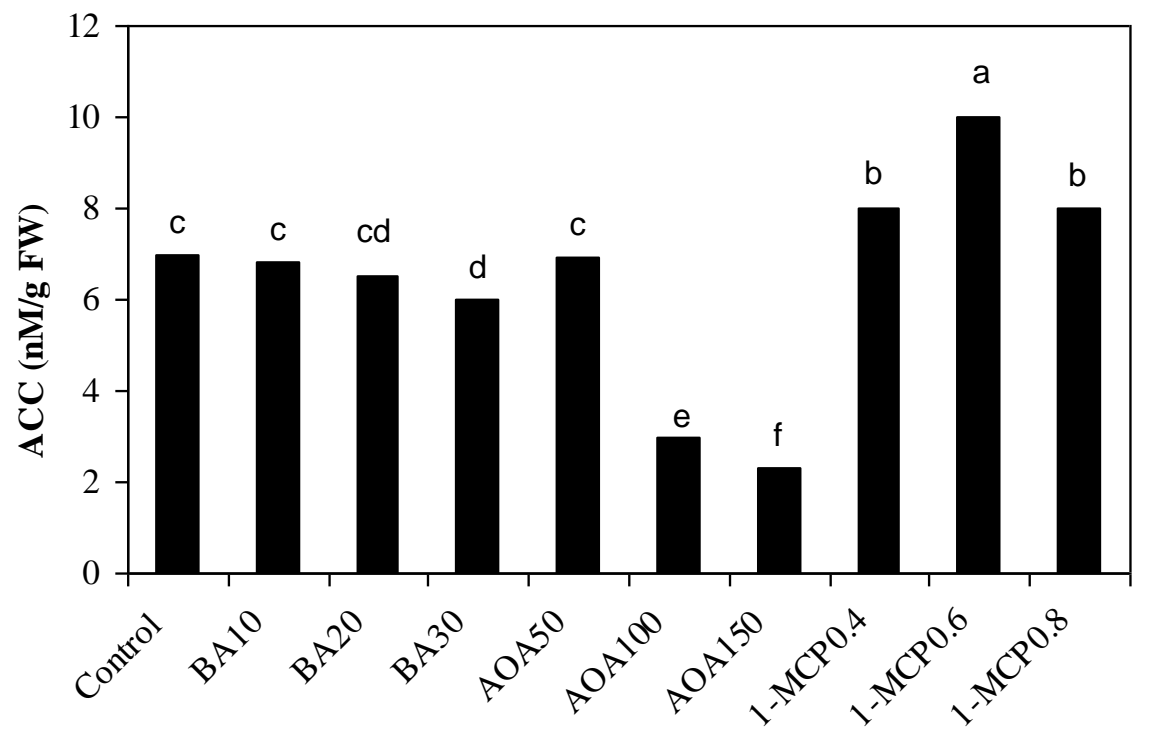

Figure 3. ACC content in flowers in response to treatment with different concentrations of $\mathrm{BA}, \mathrm{AOA}$ and 1-MCP 


\section{DISCUSSION}

Senescence has been documented to promote ethylene synthesis (Nichols, 1977). In the present study, we used 1-MCP, AOA and BA as senescence retarding agents to investigate how vase life, ethylene production, ACC content and antioxidant enzymes were affected when ethylene synthesis was inhibited. Our results showed that 1-MCP (at all concentrations), AOA (100 or $150 \mathrm{mg} \mathrm{l}^{-1}$ ) and BA (30 $\left.\mathrm{mg} \mathrm{l}^{-1}\right)$ decreased ethylene production in the flowers of cut spray carnation 'Optima' (Fig. 1). They delayed the onset of wilting in the flowers, which agrees with the findings of Lerslerwong and Ketsa (2008) for Dendrobium flowers and Segliea et al. (2011) for Dianthus caryophyllus cut flowers. AOA is a well-known inhibitor of ACC synthase (Mensuali-Sodi et al., 2005). $\mathrm{Yu}$ et al. (1979) reported that AOA inhibits the activity of ACC synthase by complexing with the essential cofactor, pyridoxal phosphate. As a result, the effect of AOA is probably due to the inhibition of ethylene production ( $\mathrm{Yu}$ et al., 1979). The success in extending the vase life of the studied cut flowers using BA could be attributed to the role of BA in inhibiting ethylene biosynthesis. These results are in agreement with the results of Cook et al. (1985) and Han and Miller (2003). Hassanpour Asil and Karimi (2010) reported that spraying cut lisianthus flowers with 25 or $50 \mathrm{mg} \mathrm{l}^{-1}$ BA delayed ethylene production and extended their vase life. Our results showed that the ap- plication of 1-MCP, an ethylene perception inhibitor, significantly decreased ethylene production rate in flowers. The decreased ethylene production in 1-MCP-treated 'Optima' flowers may have also been due to the inhibition of the autocatalytic production of ethylene (Pathak et al., 2003).

The increase in the ACC content of the petals coincided closely with the increase in ethylene production by the flowers. The ACC content of the 'Optima' flowers pre-treated with 1-MCP (especially at the concentration of $0.6 \mathrm{mg} \mathrm{l}^{-1}$ ) was clearly higher than in the untreated control. The accumulation of ACC in 1-MCP treated flowers may indicate that treatment with 1-MCP mainly reduces ACC oxidase activity and to a lesser extent ACC synthase. However, no accumulation of ACC was observed after the AOA treatment (especially at the concentration of $150 \mathrm{mg} \mathrm{l}^{-1}$ ), confirming that ACC synthase was inhibited by AOA. Muller et al. (2001) showed that treatment with $1-\mathrm{MCP}$ resulted in increased accumulation of ACC and reduced ethylene production during senescence in miniature rose flowers. They reported that no accumulation of ACC was observed after the treatment with 1-MCP and subsequent exposure to ethylene, suggesting that not only ACC oxidase but also ACC synthase was inhibited by 1-MCP (Muller et al., 2001). The oxidative metabolism has an important role at cellular level when senescence occurs. During senescence there is an over-production of free radicals such as superoxide anion 
$(\mathrm{O} 2 \bullet-)$, hydroxyl radicals $(\mathrm{OH} \bullet)$ and hydrogen peroxide $\left(\mathrm{H}_{2} \mathrm{O}_{2}\right)$, which may cause damage, leading to cell death. The harmful free radicals are controlled and balanced by antioxidant systems (Khan, 2006). Several enzymes such as SOD, CAT and POD are involved in the scavenging of free radicals in the plant system (Celikel and Van Doorn, 1995). In carnation petals, SOD activity decreases and CAT activity increases during senescence (Droillard et al., 1989). The cells mount a defence response against the accumulation of free radicals by increasing CAT and SOD activity (Khan, 2006). Larrigaudiere et al. (2004) suggested that ethylene was involved in ROS production. Our results showed that 1MCP-treated cut flowers had significantly higher SOD, CAT and POX activities compared with the control, AOA and BA treatments (Tab. 1). This is in accordance with the findings of Djanaguiraman et al. (2011) and Wang et al. (2009). The increases in SOD and POX enzymes in 1-MCP-treated flowers may be due to lower levels of ethylene production and scavenging of $\mathrm{O}_{2}^{-}$and $\mathrm{H}_{2} \mathrm{O}_{2}$. (Larrigaudiere et al., 2004). This study on antioxidant metabolism of cut spray carnation petals can be understood /regarded? not only as experimental evidence confirming the hypothesis of a link between ethylene and free radicals generation in senescence, but also as a key to the development of adequate methods to prevent or delay deterioration in cut flowers.

\section{CONCLUSIONS}

In conclusion, the data obtained in the study has shown that treatment with AOA, BA (at high concentration) or 1-MCP could be a good remedy for extending vase life. The treatments with AOA (100 and $150 \mathrm{mg} \mathrm{l}^{-1}$ ), BA (30 $\mathrm{mg} \mathrm{l}^{-1}$ ) and 1MCP prevented an increase in ethylene production and increased the antioxidant enzyme activity measured in petals.

\section{REFERENCES}

Aebi H.E. 1983. Catalase. In: Bergmeyer H.U. (ed.), Methods of Enzymatic Analysis, Vol. 3. Verlag Chemie, Weinheim. Academic Press, New York, pp. 273-285.

Beauchamp C.H., Fridovich I. 1971. Superoxide dismutase: improved assays and an assay applicable to acrylamide gels. ANAL. BIOCHEM. 44: 276-87.

Bulens I., Van de Poel B., Hertog M.L., Proft M., Geeraerd A.H., Nicola B.M. 2011. Protocol: An updated integrated methodology for analysis of metabolites and enzyme activities of ethylene biosynthesis. PLANT METHODS 7:17.

Carlos G., Marcela Simontacchi B., Montaldi E., Puntarulo P. 1996. Oxidative stress, antioxidant capacity and ethylene production during ageing of cut carnation (Dianthus caryophyllus) petals. J. EXP. BOT. 47(297): 595-601.

Celikel F.G., Van Doorn W.G. 1995. Solute leakage lipid peroxidation, and protein degradation during the senescence of Iris tepals. PHYSIOL. PLANT. 94: 515-521.

Cook D., Rasche M., Eisinger W. 1985. Regulation of ethylene biosynthesis 
and action in cut carnation flower senescence by cytokinins. J. AM. SOC. HORT. SCI. 110: 24-27.

Djanaguiraman M., Prasad P.V.V., AlKhatib L. 2011. Ethylene perception inhibitor 1-MCP decreases oxidative damage of leaves through enhanced antioxidant defense mechanisms in soybean plants grown under high temperature stress. ENVIRON. EXPER. BOT. 71: 215-223.

Dhindsa R.S., Pulp- Dhindsa P., Thorpe T.A. 1981. Leaf senescence: correlated with increased levels of membrane permeability and lipid peroxidation and decreased levels of superoxide dismutase and catalase. J. EXP. BOT. 32: 93-101.

Droillard M., Bureau J.D, Paulin A. 1989. Changes in activities of superoxide dismutase during aging of petals of cut carnations (Dianthus caryophyllus). PHYSIOL. PLANT. 76: 149-154.

Ferrante A., Mensuali-Sodi A., Serra G., Tognoni F. 2006. Evaluation of postproduction performance of Salvia splendens potted plants for interiors use. ACTA HORT. 723: 415-419.

Han S.S., Miller J.A. 2003. Role of ethylene in postharvest quality of cut oriental lily 'Stargazer'. PLANT GROWTH REGUL. 40: 213-222.

Hassanpour Asil M, Karimi M. 2010. Efficiency of benzyladenine reduced ethylene production and extending vase life of cut Eustoma flowers. PLANT OMICS 3:199-203.

Huang K.L., Chen W.S. 2002. BA and sucrose increase vase life of cut Eustoma flower. HORT. SCI. 37: 547549.

Karimi M., Hassanpour Asil M. 2010. Role of benzyladenine on vase life and quality of cut lisianthus flowers. HORT. ENVIRON. BIOTECHNOL. 51: 284-287.
Khan N.A. 2006. Ethylene action in plants. Springer. Springer-Verlag Berlin Heidelberg, Netherlands, pp. 206.

Larrigaudiere C., Vilaplana R., Soria Y., Recasens I. 2004. Oxidative behaviour of Blanquilla pears treated with 1-methylcyclopropene during cold storage. J. SCI. FOOD AGRIC. 84: 1871-1877.

Lerslerwong L., Ketsa S. 2008. Autocatalytic ethylene production by Dendrobium flowers during senescence induced by exogenous ethylene. THAI J. AGRIC. SCI. 41: 91-99.

Macnisha A.J., Jiang C., Reida M.S. 2010. Treatment with thidiazuron improves opening and vase life of iris flowers. POSTHARVEST BIOL. TECHNOL. 56: 77-84.

Mayak S., Legge R.L., Thompson J.E. 1983. Superoxide radical production by microsomal membranes from senescing carnation flowers: an effect on membrane fluidity. PHYTOCHEMISTRY 11: 1375-1380.

McCord J.M., Fridovich I. 1969. Superoxide dismutase. Enzymatic function forerithrocuprein (hemocuprein). J. BIOL. CHEM. 244: 6049-6055.

Mensuali-Sodi A., Ferrante A., Tognoni F., Serra G. 2005. Inhibitors of ethylene action and biosynthesis on cut carnation. AGRIC MEDITERRANEA 135: 161165.

Muller R., Stummann B.M., Sisler E.C., Serek M. 2001 Cultivar differences in regulation of ethylene production in miniature Rose flowers (Rosa hybrida L.). GARTENBAUWISSENSCHAFT 66: 34-38.

Nichols R. 1977. Sites of ethylene production in the pollinated and unpollinated senescing carnation (Dianthus caryophyllus) inflorescence. PLANTA 135: 155-159.

Pathak N., Asif M.H, Dhawan P., Srivastava M.K., Nath P. 2003. Ex- 
M. Karimi et al.

pression and activities of ethylene biosynthesis enzymes during ripening of banana fruits and effect of 1-MCP treatment. PLANT GROWTH REGUL. 40: 11-19.

Pemberton H.B., Kelly J.W., Ferare J., Armitage A. 1997. Pot Rose Production. Timber Press, Portland, Oregon, USA, pp. 112-117.

Rattanawisalanona C., Ketsa S., van Doorn W.G. 2003. Effect of aminooxyacetic acid and sugars on the vase life of Dendrobium flowers. POSTHARVEST BIOL. TECHNOL. 29: 93-100.

Segliea L., Martinab K., Devecchia M., Roggerod C., Trottac F., Scariota V. 2011. The effects of 1-MCP in cyclo- dextrin-based nanosponges to improve the vase life of Dianthus caryophyllus cut flowers. POSTHARVEST BIOL. TECHNOL. 59: 200-205.

Serek M., Sisler E.C., Reid M.S. 1995. Effects of 1-MCP on the vase life and ethylene response of cut flowers. PLANT GROWTH REGUL. 16: 93-97.

Wang B., Wang J., Feng X., Zhao Y., Jiang W. 2009. Effects of 1-MCP and exogenous ethylene on fruit ripening and antioxidants in stored mango. PLANT GROWTH REGUL. 57: 185-192.

Yu Y.B., Adams D.O., Yang S.F. 1979. 1-aminocyclopropane-1-carboxylate synthase, a key enzyme in ethylene biosynthesis. ARCH. BIOCHEM. BIOPHYS. 198: 289-286.

\title{
WPŁYW ZABIEGÓW Z INHIBITORAMI ETYLENU NA WYTWARZANIE ETYLENU I AKTYWNOŚĆ ANTYOKSYDACYJNĄ W KWIATACH CIĘTYCH GOŹDZIKA OGRODOWEGO
}

\author{
Mahnaz Karimi, Moazzam Hassanpour Asil, \\ Ghorbanali Nematzadeh i Hedayat Zakizadeh
}

\author{
S T R E S Z C Z E N I E
}

Badania miały na celu zbadanie zmian w wytwarzaniu etylenu, zawartości kwasu 1-aminocyklopropano-1-karboksylowego (ACC) oraz enzymów antyoksydacyjnych w kwiatach ciętych goździka ogrodowego (Dianthus caryophyllus L.), które były poddane działaniu kwasu aminooksyoctowego (AOA), benzyloadeniny (BA) i 1 metylocyklopropenu (MCP-1). Maksymalną trwałość kwiatów ciętych odmiany goździka ogrodowego „Optima” uzyskano stosując $0,6 \mathrm{mg} \mathrm{l}^{-1}$ 1-MCP. W porównaniu z kontrolą wytwarzanie etylenu istotnie zmniejszyło się po zastosowaniu AOA w stężeniu powyżej $100 \mathrm{mg} \mathrm{l}^{-1}$, BA w stężeniu $30 \mathrm{mg} \mathrm{l}^{-1}$, i 1-MCP we wszystkich stężeniach. Istotny wzrost zawartości ACC w porównaniu z kontrolą zaobserwowano w kwiatach ciętych traktowanych 1-MCP. Spadek zawartości ACC zaobserwowano jednak po zastosowaniu $100 \mathrm{lub} 150 \mathrm{mg} \mathrm{l}^{-1}$ AOA. Istotny wzrost aktywności enzymów SOD, CAT i POX stwierdzono w kombinacji z $0,6 \mathrm{mg} \mathrm{l}^{-1} 1-\mathrm{MCP}$.

Słowa kluczowe: kwas aminooksyoctowy, benzyloadenina, 1-metylcyklopropen, trwałość kwiatów ciętych 